\title{
Genotype in Hepatitis B Patients in Tertiary Care Hospital in North Zone of India
}

\author{
Neeru Rajput*, Shashi S. Sharma, Vijant Chandail, Bella Mahajan, \\ Kanika Razdan, Perika Sharma and Priyanka Sharma
}

Government Medical College (GMC) Jammu, India

*Corresponding author

\section{A B S T R A C T}

\begin{tabular}{l} 
Ke y w o r d s \\
HBV genotypes, \\
Serological \\
positive, \\
Genotype D \\
\hline Article Info \\
$\begin{array}{l}\text { Accepted: } \\
\text { 28 March } 2020 \\
\text { Available Online: } \\
10 \text { April } 2020\end{array}$ \\
\hline
\end{tabular}

\section{Introduction}

Hepatitis B virus (HBV) induces a range of liver diseases, ranging from acute or fulminant Hepatitis to liver cirrhosis (LC) and hepatocellular carcinoma $(\mathrm{HCC})^{(1)}$. Hepatitis is self-limiting in most adult patients with acute infection but approximate $1 \%-2 \%$ of patients progress to fulminant hepatic failure, while some progress to chronic infection ${ }^{(2)}$. The rate of progression from acute to chronic HBV infection is reported to be $90 \%$ in newborns and $5 \%-10 \%$ in adults ${ }^{(3)}$. HBV is largely transmitted through exposure to body fluids containing the virus through unprotected sexual contact, blood transfusions, re-use of contaminated needles, vertical transmission from mother to child during birth ${ }^{(4)}$.

Other risk factors for developing HBV infection are occupational linked like working in a health care setting related to transfusion, dialysis, acupuncture, tattooing, and residence in an institution ${ }^{(5)}$. HBV was discovered by Blumberg in $1965^{(6)}$. HBV was initially known as serum hepatitis ${ }^{(7)}$. HBV is a small DNA virus with unusual features similar to 
retroviruses $^{(8)}$. The genome of HBV is a partially double-stranded circular DNA of about 3.2 kilobase (kb) pairs ${ }^{(9)}$. HBV sequence is characterized by $>8 \%$ nucleotide differences for genotype and on this bases HBV is characterized into ten genotypes that is $\mathrm{A}$ to $\mathbf{J}^{(10)}$. Relationship between different genotypes and geographical distribution with relation to disease progression, prognosis and response to antiviral treatment is also studied and documented ${ }^{(11)}$.

Geographic distribution of HBV genotypes may be correlated to route of exposure for example; genotypes $\mathrm{B}$ and $\mathrm{C}$ are more common in high-endemic regions and are associated with perinatal or vertical route of viral transmission ${ }^{(12)}$. For A, D, E route of exposure is pivotal in predicting disease progression and determine appropriate antiviral therapy e.g. acute infection with genotypes $\mathrm{A}$ and $\mathrm{D}$ leads to higher rate of chronicity $^{(13)}$. Genotype C generally is considered as a risk factor for perinatal infection $^{(14)}$ and related to severe liver disease, including cirrhosis and $\mathrm{HCC}^{(15,16,17)}$. Patients infected with genotype $\mathrm{B}$ or $\mathrm{C}$ have a lower opportunity to gain serological response to tenofovir ${ }^{(18,19)}$

All genotypes A, B, C and D except for E, G and $\mathrm{H}$ are subdivided into several geographically localized subgenotype ${ }^{(20)}$. Subgenotype A1 in central and Southern Africa, subgenotype A2 predominates in northern Europe, subgenotypes B1-B7, $\mathrm{C}_{1}$ and $\mathrm{C} 2$ predominate in $\mathrm{Asia}^{(21)}$ while $\mathrm{C} 3, \mathrm{C} 4$ and D4 are the most prevalent on the Australian continent.

\section{Materials and Methods}

It was research and observational study done at Govt. Medical college hospital after having permission from Institutional Ethical Committee (IEC) of Government Medical
College (GMC) Jammu. Sample received for testing of $\mathrm{HBV}$ infection $\mathrm{GMCH}$ to OPD (collection centre) of Microbiology GMC Jammu taken in duration of one year (November 2017 to November 2018). Samples were collected from patients of chronic hepatitis $\mathrm{B}$, positive for $\mathrm{HBsAg}$ and above 15 years of age with exclusion criteria of patient of acute hepatitis, Cirrhosis, HCC and patient positive for $\mathrm{HBsAg}$, but at same time positive for anti-HDV, anti-HCV or anti -HIV and pregnant women.

$5 \mathrm{ml}$ of venous blood was collected from chronic HBV patients attending to the Medicine OPD of Government Medical College (GMC) Jammu. Samples were sent to Department of Microbiology GMC Jammu for further processing. Serum was separated by centrifugation, aliquoted and stored at $20^{\circ}$ C. Serum was tested for HBeAg Enzyme linked immunosorbent assay (ELISA) for HBeAg (Make: Bioneovan). Test was performed as per manufactures instructions. All the samples positive for $\mathrm{HBeAg}$ were subjected to DNA extraction by Viral DNA extraction kit (Make: Machery Nagel). Primer sequence was designed $^{(22)}$.

P1b -: TCACCATATTCTTGGGAACAAGA (number of bases 23)

S1-2-: CGAACCACTGAACAAATGGC (number of bases 20)

B2-: GGCTCMAGTTCMGGAACAGT (number of bases 20)

BA1R CTCGCGGAGATTGACGAGATGT (number of bases 22)

BB1R

CAGGTTGGTGAGTGACTGGAGA (number of bases 22)

BC1R -: GGTCCTAGGAATCCTGATGTTG (number of bases 22)

BD1-: $\quad$ GCCAACAAGGTAGGAGCT (number of bases 18)

BE1 


\section{CACCAGAAATCCAGATTGGGACCA}

(number of bases24)

The extracted DNA is subjected to multiplex PCR with PCR primers (outer primer pairs and inner primer pairs) designed on the basis of the conserved nature of nucleotide sequences in regions of the pre-S1 through $\mathrm{S}$ genes, irrespective of the six HBV genotypes. P1 (sense) and S1-2 (antisense) with universal outer primers \& inner primer $(\text { sense })^{22}$. Extracted DNA \& PCR primers will be subjected to PCR cycles.

As PCR completed the product will be subjected into electrophoresis on $1 \%$ agarose gel. Sample was loaded in respected well and run at 75 volts for $2 \mathrm{hrs}$. The sizes of PCR products are estimated according to the migration pattern of a $100 \mathrm{bp}$ DNA ladder. Gel was visualized under UV light in E gel imager (Applied biosystem). The gel will then stained by ethidium bromide, the results adjacent to DNA ladder $100 \mathrm{bp}$ will be viewed under UV light ${ }^{23}$.

\section{Results and Discussion}

Among 50 patients, 29 were positive for HBeAg from $29 \mathrm{HBeAg}$ positive samples, 26 samples showed genotype whereas in 3 samples no genotype was detected. In our study, out of 50 chronic hepatitis B infected patients, $29(58 \%)$ samples were positive for $\mathrm{HBeAg}$. Out of which 26 were positive for Genotype D and in 3 samples no genotype was detected.

Non detection of genotype in three patients would, be due to low viral load, technical error or patients were on treatment since longer duration. Chattopadhyay et al., $2006^{(24}$ detected most common genotype D (62.2\%) from New Delhi and Tuteja et al., 2014 ${ }^{(25)}$ reported most common genotype D (62.2\%) from Punjab, Himachal Pradesh, Delhi and other regions of North India. Study done in
Uttar Pradesh on 105 samples by Kumar et al., 2011 $1^{(26)}$ and all HBeAg. Positive and HBeAg negative sample were subjected to PCR genotyping and Genotype D was detected. $78 \%$ genotype $\mathrm{D}$ was reported by Rizvi, (2018) ${ }^{(27)}$ in Northern region of India. Kumar et al., $(2011)^{(26)}$ reported most common genotype A $(53 \%)$ in Bihar, Eastern India. Mukherjee et al., (2013) ${ }^{(28)}$ detected most common genotype D $(84 \%)$ in Hyderbad.

Biswas et al., $(2013)^{(29)}$ detected most common genotype A from Eastern India. Borkakotry et al., (2008) ${ }^{(30)}$ reported genotype A $(41.6 \%)$ in Arunachal Pradesh, Assam, eastern state of India. Banerjee et al., 2006 ${ }^{(31)}$ and Chandra et al., $(2007)^{(32)}$ reported genotype D (49.6\%) from Kolkata. Ismail et al., $(2014)^{(33)}$ reported Genotype D $(77 \%)$ in Andhra Pradesh, Chennai and south part on India.

Gopal Krishnan et al., $2013^{(34)}$ reported Genotype $\mathrm{A}(72 \%)$ in Kerala, South part on India. Kumar et al., (2011) ${ }^{(26)}$ reported that Western India and the Andaman and Nicobr Islands originally both genotype $\mathrm{A}$ and genotype $\mathrm{D}$ were in equal proportion but latter genotype $\mathrm{D}$ was most predominant over genotype A. Shrestha et al., 2012 $2^{(35)}$ reported genotype D from Nepal.

Mahmood et al., $2016^{(36)}$ conducted study at Pakistan reported that most common genotyped D (71.2\%) followed by genotypes A. Ansari et al., 2015, ${ }^{(10)}$ Imam Khomeini Hospital of Ahvaz and reported most common genotype D. Ayaz et al., $2013^{(37)}$ conducted study at Kohat region of Khyber Pakhtunkhwa in Pakistan and concluded that genotype A, C, D and F were the most common genotypes. Rahman et al., $(2016)^{(38)}$ detected genotype A in Bangladesh. Ying Ma et al., 2011 ${ }^{(39)}$ identified genotype C dominant genotype in patients from Shenyang, China (Fig.1a-d). 
Sample No.

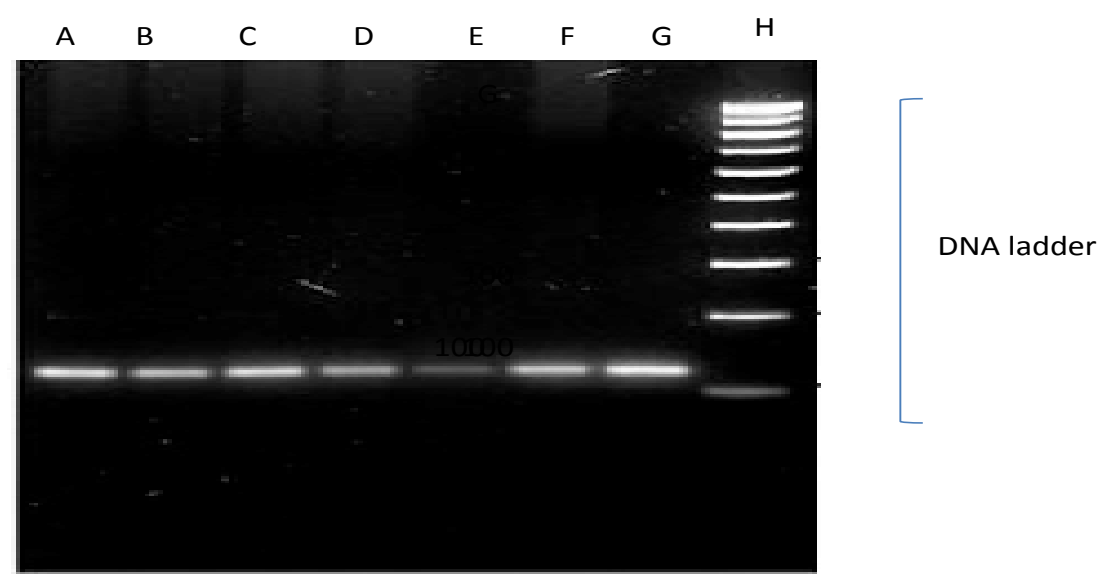

Fig.1a I indicate DNA ladder 100bp (Make:Qiagen) and A,B,C,D,E,F and G are sample number $1,2,3,5.6 .13$ and 14

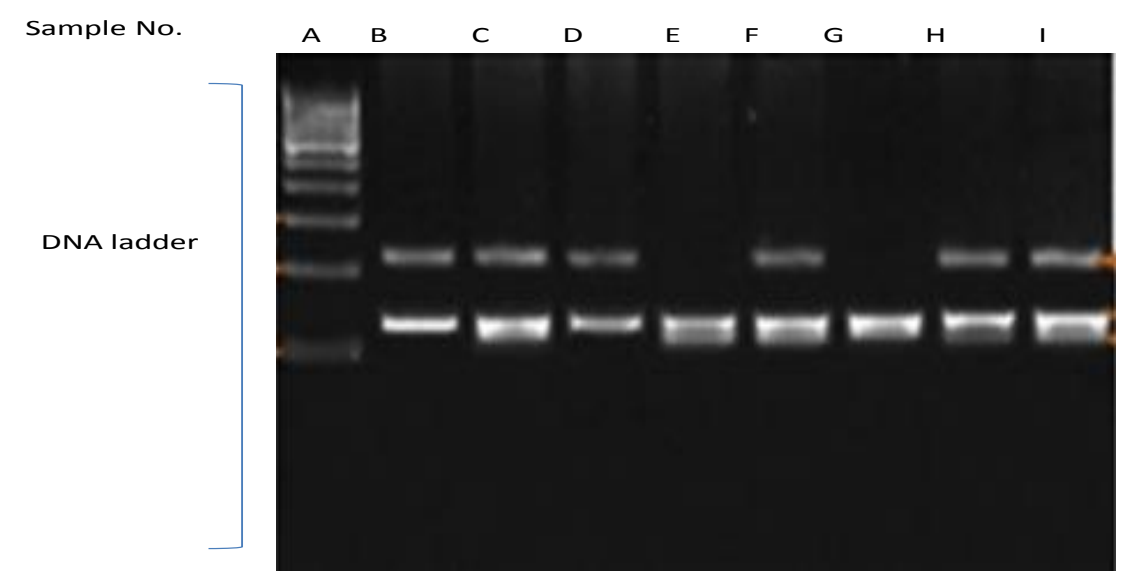

Fig.1b A indicate DNA ladder 100bp (Make:Qiagen) and B,C,D,E,F,G and $\mathrm{H}$ are sample number $16,17,18,22,24,25,27$ and 28

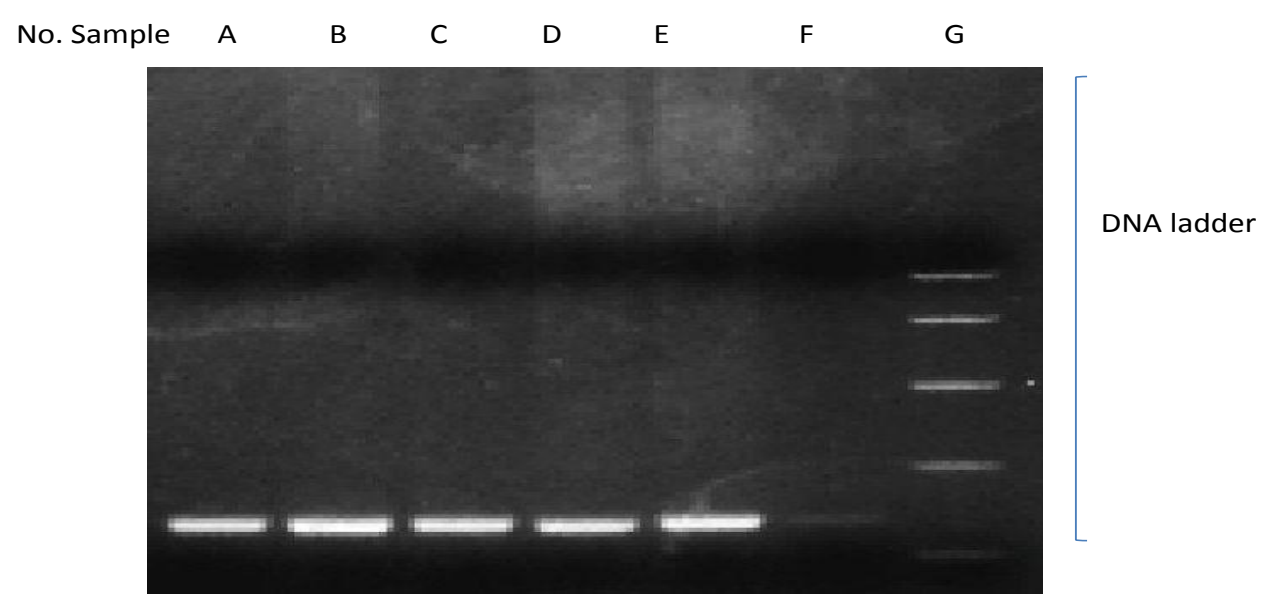

Fig.1c G indicate DNA ladder 100bp (Make:Qiagen) and A,B,C,D,E,F and G are sample number $32,38,39,40,41$, and 42 


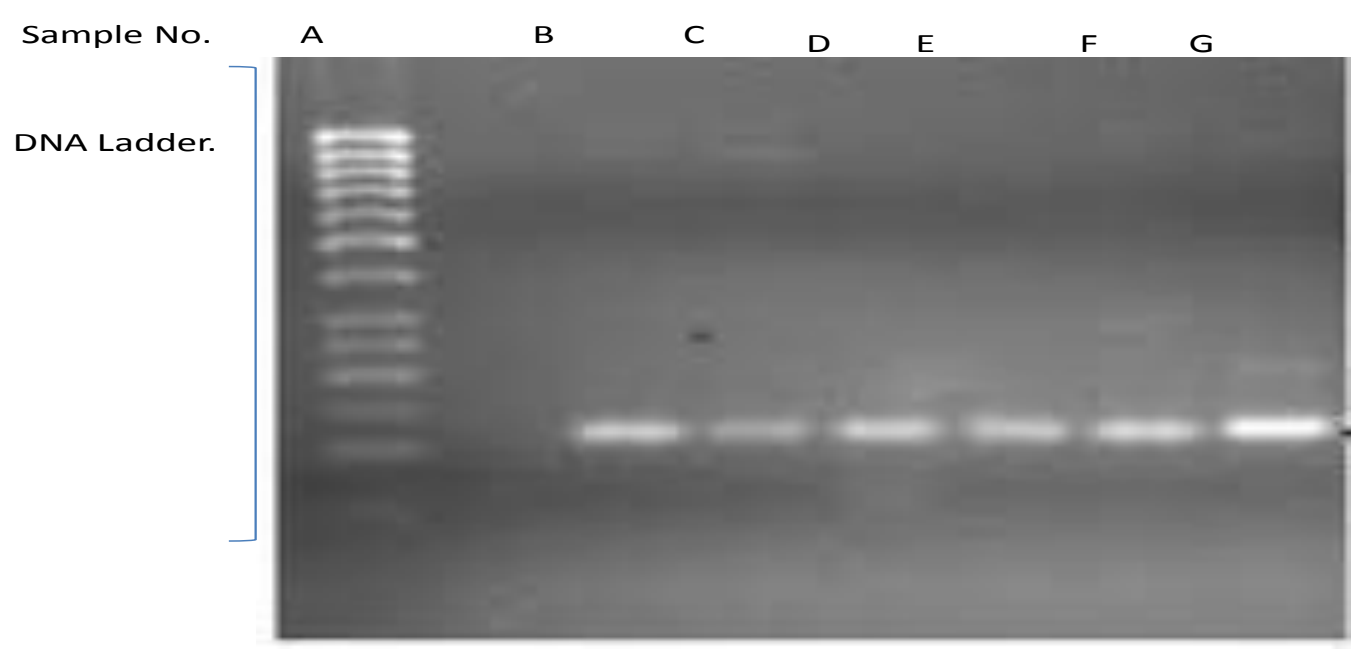

Fig.1d A indicate DNA ladder 100bp(Make:Qiagen) and B,C,D,E, and G are sample number $44,45,46,48,49$, and 50.

In the study genotype D was reported whereas in similar study from neighboring state of our region, Himachal Pradesh, Punjab, Delhi most common genotype reported was genotype D. In neighboring state of our region Pakistan, Nepal, Pakistan occupied Kashmir genotype $D$ was reported. Therefore because of geographical niches and due to marriages and duty posting in neighboring states and due travelling in neighboring countries could be the reason for detection of genotype D.

\section{References}

1.Michitaka K, Nishiguchi S. Etiology of liver cirrohosis in japan a Nationwide survey.J Gastroenterol 2010;45(1): 86-94.

2.Yim HJ, Lok AS. Natural history of chronic hepatitis B virus infection. Hepatology 2006; 43 (S1): S173-81

3.Hoofnagle JH, DooE, Liang TJ, Fleischer R, Lok ASF. Management of hepatitis B. Summary of a clinical research workshop. $J$ Hepatol 2007; 45(4): 1056-75.

4.Sharma N, Kandpal J, Nautiyal SC, Rawat S, Singh AP, Talwar A et al., Real Time PCR Usage in the Quantification of Hepatitis B Virus DNA-Clinical Applications in Disease Management. Int $J$ Pharma
Research \& Review 2013; 2(6): 45-51.

5.Aspinall EJ, Hawkins G, Fraser A, Hutchinson SJ, Goldberg D. Hepatitis B prevention, diagnosis, treatment and care: a review. Occupational Medicine 2011; 61: 531-40.

6.Pourkarim MR, Amini-Bavil-Olyaee S, Kurbanov F, Ranst MV, and Frank. Tacke Molecular identification of hepatitis B virus genotypes/subgenotypes: Revised classification hurdles and updated resolutions. World J Gastroenterol. 2014 ; 20(23): 7152-168.

7.Ghafourian S, Mohebi R, khosravi A, MalekiA, Davoodian A, Sadeghifard N. Detection of Hepatitis B Virus DNA by Real-Time PCR in Chronic Hepatitis B Patients, Ilam, Iran. Middle-East J Sci Res 2011; 9(4): 478-80.

8.Potdar P, Tyagi S. HBx gene expression is a sensitive indicator of chronic Hepatitis B infection than expression of HBV Surface, Core and Polymerase gene. Int $J$ Curr Microbiol App Sci 2014; 3(10): 20-30.

9.Dienstag DL, Anthony S, Fauci, harrison S. Acute Viral Hepatitis. Principles of internal Medicine, Volume II, 17th. United States of America. McGraw Hill Medical 2008; 1932.

10.Ansari N, Makvandi M, Zadeh AZS. Hepatitis $\mathrm{B}$ virus Genotyping Among Patients with Cirrhosis. Jundishapur J Microbiol. 2015; 
8(3): 14571-80.

11.Kao JH. Diagnosis of hepatitis B virus infection through serological and virological markers. Expert Rev Gastroenterol Hepatol 2008; 2: 553-62.

12.Sunbul M. Hepatitis B virus genotypes: Global distribution and clinical importance. World J Hepatol 2014; 20(18): 5427-34.

13.Song J E, Kim DY. Diagnosis of hepatitis B. ATM 2016; 4(18): 338-44.

14.Ding Y, Sheng Q, Ma L. Chronic HBV infection among pregnant women and their infants in Shenyang, China. Virol J 2013; 10:7.

15.Lee MH, Yang HI, Liu J. Prediction models of long-term cirrhosis and hepatocellular carcinoma risk in chronic hepatitis B patients: risk scores integrating host and virus profiles. Hepatology 2013; 58: 54654.

16. Kim DW, Lee SA, Hwang ES. Naturally occurring precore/ core region mutations of hepatitis $\mathrm{B}$ virus genotype $\mathrm{C}$ related to hepatocellular carcinoma. PLoS One 2012; 7: 47372 .

17.Lee SA, Kim K, Kim H. Nucleotide change of codon 182 in the surface gene of hepatitis B virus genotype $\mathrm{C}$ leading to truncated surface protein is associated with progression of liver diseases. J Hepatol 2012; 56: 63-9.

18.Chan HL, Chan CK, Hui AJ. Effects of tenofovir disoproxil fumarate in hepatitis B e antigen- positive patients with normal levels of alanine aminotransferase and high levels of hepatitis B virus DNA. Gastroenterology 2014; 146: 1240-8.

15.Lee MH, Yang HI, Liu J. Prediction models of long-term cirrhosis and hepatocellular carcinoma risk in chronic hepatitis B patients: risk scores integrating host and virus profiles. Hepatology 2013; 58: 54654.

16.Kim DW, Lee SA, Hwang ES. Naturally occurring precore/ core region mutations of hepatitis B virus genotype C related to hepatocellular carcinoma. PLoS One 2012; 7: 47372.

17.Lee SA, Kim K, Kim H. Nucleotide change of codon 182 in the surface gene of hepatitis B virus genotype $\mathrm{C}$ leading to truncated surface protein is associated with progression of liver diseases. J Hepatol 2012; 56: 63-9.

18.Chan HL, Chan CK, Hui AJ. Effects of tenofovir disoproxil fumarate in hepatitis B e antigen- positive patients with normal levels of alanine aminotransferase and high levels of hepatitis B virus DNA. Gastroenterology 2014; 146: 1240-8.

19.Marcellin P, Buti M, Krastev Z. Kinetics of hepatitis B surface antigen loss in patients with Hbe Ag-positive chronic hepatitis B treated with tenofovir disoproxil fumarate. $J$ Hepatol 2014; 61: 1228-37.

20.Schaefer S. Hepatitis B virus taxonomy and hepatitis B virus genotypes. World $J$ Gastroenterol 2007; 13: 14-21.

21.Kurbanov F, Tanaka Y, Mizokami M. Geographical and genetic diversity of the human hepatitis B virus. Hepatol Res 2010; 40: 14-30.

22. Yoosefi K, Taheri M, Khosravi S, SaneieMoghadam E, Mohagheghi-Fard HA. Genotyping of Hepatitis B Virus by Multiplex PCR in Sistan and Baluchestan Province. Zahedan. $J$ of Res in Med Sci 2015; 10(10): 29- 33.

23.Shigeki HHN, Abe K. Rapid and Specific Genotyping System for Hepatitis B Virus Corresponding to Six Major Genotypes by PCR Using Type-Specific Primers. J Clin Microbiol 2001; 39( 1): 362-4.

24.Chattopadhyay S, Das BC, Kar P. Hepatitis B virus genotypes in chronic liver disease patients from New Delhi, India. World J Gastroenterol 2006; 12: 67026.

25. Tuteja A, Siddiqui AB, Madan K, Goyal R, Shalimar, Sreenivas V, et al., Mutation profiling of the hepatitis B virus strains circulating in North Indian population. PLOS One 2014; 9.

26. Kumar A, Dwivedi M, Misra SK, Misra V, Narang S, Pandey R, et al., Distribution of Hepatitis B Virus Genotypes and Its Association with Severity of Liver Disease in Patients with Chronic Hepatitis B in Uttar Pradesh, India. Indian J Virol2011; 22(1): 24-8.

27. Rizvi M, Azam M, Sultan A, Shukla I, Malik A, Ajmal MR, et al., Prevalence

of genotype $\mathrm{D}$ in chronic liver disease patients 
with occult HBV infection in northern region of India. Indian Journal of Pathology and Microbiology 2014; 57(4): 537- 41.

28.Mukherjee RM, Balkumar Reddy P, Sasikala M, Nagaraja Rao P, Nageshwar, Reddy D. Identification of genotype $\mathrm{B}$ among hepatitis B virus-infected patients in Hyderabad, India. Ann Hepatol 2009; 8: 269-70.

29.Biswas A, Panigrahi R, Pal M, Chakraborty S, Bhattacharya $\mathrm{P}$, Chakrabarti S, et al., Shift in the hepatitis $B$ virus genotype distribution in the last decade among the HBV carriers from eastern India: possible effects on the disease status and HBV epidemiology. J Med Virol 2013; 85: 1340 7.

30.Borkakoty BJ, Mahanta J, Biswas D. Circulating genotypes of hepatitis B virus in Arunachal Pradesh. Indian J Med Res 2008; 127: 65-70.

31.Banerjee A, Datta S, Chandra PK, Roychowdhury S, Panda CK, Chakravarty R. Distribution of hepatitis B virus genotypes: phylogenetic analysis and virological characteristics of genotype $\mathrm{C}$ circulating among HBV carriers in Kolkata, Eastern India. World J Gastroenterol 2006; 12: 5964-971.

32.Chandra PK, Banerjee A, Datta S, Chakravarty R. G1862T mutation among hepatitis B virus-infected individuals: association with viral genotypes and disease outcome in Kolkata, Eastern India. Intervirology 2007; 50: 173-180.

33.Ismail AM, Puhazhenthi KS, Sivakumar J, Eapen CE, Kannangai R, AbrahamP.
Molecular epidemiology and genetic characterization of hepatitis B virus in the Indian subcontinent. Int J Infect Dis 2014; 20:1-10.

34.Gopalakrishnan D, Keyter M, Shenoy KT, Leena KB, Thayumanavan L,Thomas $\mathrm{V}$, et al., Hepatitis B virus subgenotype A1 predominates in liver disease patients from Kerala, India. World J Gastroenterol 2013; 19: 9294-306.

35.Shrestha SM, Shrestha D. Chronic hepatitis B in Nepal: An Asian country with low prevalence of HBV Infection. Tropical Gastroentrology 2012; 24.

36. Mahmood M, Muhammad AA, Azar K, Zaman $\mathrm{N}$ and Abida R. Distribution and clinical significance of hepatitis B virus genotypes in Pakistan. BMC Gastroenterology 2016; 104: 16.

37.Ayaz S, Mohammad A, Khan S, Wasir FU, Hussian M, Akhtar M. Hepatitis B virus Genotypes from Clinical Sample of Hepatitis B Antigen Positive Patients by Using PCR Method in Kohat Region of Khyber Pakhtunkhwa, Pakistan. Pak. j. life soc. Sci. 2013; 11(2): 112- 17.

38.Rahman A, Hakim F,Chowdhury MA, Ashan AC, NessaJ, Mahmuda Y. Revalence of genotypes and subtypes of hepatitis B viruses in Bangladeshi population. Springer Plus 2016; 5: 278.

39. Ying MZ, Ying Ding, Feng juan, Xiao gu. Genotyping the hepatitis B virus with a fragment of the HBV DNA polymerase gene in Shenyang, China. Virol J 2011; 8: 315 .

\section{How to cite this article:}

Neeru Rajput, Shashi S. Sharma, Vijant Chandail, Bella Mahajan, Kanika Razdan, Perika Sharma and Priyanka Sharma. 2020. Genotype in Hepatitis B Patients in Tertiary Care Hospital in North Zone of India. Int.J.Curr.Microbiol.App.Sci. 9(04): 3118-3124.

doi: https://doi.org/10.20546/ijcmas.2020.904.364 